\title{
Training on waste management into a useful product in Bunipah Village, Banjar Regency
}

\section{Pelatihan pengelolaan sampah menjadi produk yang berdayaguna di Desa Bunipah Kabupaten Banjar}

\section{Mufatihatul Aziza Nisa, Nur Lina Wati, Aprilia Artati Nur, Fitria Fitria, Karina Nurfatma Apriani, Reki Ranggafu Fajrin}

Departemen Kesehatan Masyarakat, Fakultas Kedokteran, Universitas Lambung Mangkurat Jl. Brigjend Hasan Basri, Pangeran, Banjarmasin, 70123, Indonesia

\author{
ARTICLE INFO: \\ Received: 2021-05-11 \\ Revised: 2021-08-14 \\ Accepted: 2021-11-27 \\ Keywords: \\ Attitude, Knowledge, \\ Training, Useful \\ product, Waste \\ management
}

\begin{abstract}
Garbage is anything that is no longer used, disliked, even something that must be thrown away. Lack of public awareness and knowledge regarding waste disposal and waste management will result in community participation itself in protecting the surrounding environment. This community service program was carried out at RT 03 Bunipah Village, Aluh-Aluh District, Banjar Regency, South Kalimantan. This program is conducted online through WhatsApp groups. The goal is to increase public knowledge and insight about waste and its management in order to form awareness and good behavior for waste management. The community is expected to be able to manage waste into useful products such as compost and crafts. The results of the Wilcoxon test on the results of the pre-post test of knowledge about waste management showed differences in the knowledge and attitudes of the community before and after the intervention was given in the form of waste management training through posters, booklets, and videos, while the results of the t-test on the results of the pre-post test of attitudes about waste management The results showed that there was no difference in the knowledge and attitudes of the community before and after being given the training.
\end{abstract}

(C) 2022 Abdimas: Jurnal Pengabdian Masyarakat Universitas Merdeka Malang This is an open access article distributed under the CC BY-SA 4.0 license (https://creativecommons.org/licenses/by-sa/4.0/)

How to cite: Nisa, M. A., Wati, N. L., Nur, A. A., Fitria, F., Apriani, K. N., \& Fajrin, R. R. (2022). Training on waste management into a useful product in Bunipah Village, Banjar Regency. Abdimas: Jurnal Pengabdian Masyarakat Universitas Merdeka Malang, 7(1), 11-19. https://doi.org/10.26905/abdimas.v7i1.5791

\section{PENDAHULUAN}

Sampah adalah segala sesuatu yang sudah tidak dipakai, tidak disenangi, bahkan sesuatu yang harus dibuang. Sampah pada umumnya dihasilkan dari manusia yang berkegiatan (Hardiyanti, 2021). Selain itu, pengertian sampah juga terdapat pada Undang-Undang Nomor 18 Tahun 2008 tentang Pengelolaan Sampah yang didefinisikan Pengelolaan sampah adalah kegiatan yang sistematis, menyeluruh, dan berkesinambungan yang meliputi pengurangan dan penanganan sampah. Seiring dengan meningkatnya jumlah penduduk di suatu wilayah maka juga mengakibatkan bertambahnya volume sampah. Sampah 
ABDIMAS: Jurnal Pengabdian Masyarakat Universitas Merdeka Malang

Volume 7, No 1, February 2022: 11-19

rumah tangga merupakan salah satu sumber sampah yang cukup besar peranannya dalam peningkatan volume sampah di suatu lingkungan (Sari et al., 2018).

Minimnya pengetahuan tentang kebermanfaatan sampah ini menjadi faktor utama menumpuknya sampah. Sampah yang seharusnya bisa dimanfaatkan dan dipisah menjadi sampah organik dan sampah anorganik tidak ditangani dengan benar. Sampah harus mendapat perhatian yang serius dari instansi yang bertanggung jawab di setiap daerah untuk mencegah atau memperkecil pencemaran yang dapat ditimbulkan. Sampah yang terus bertambah, membuat sebagian orang berpikir dan melakukan aksi nyata bagaimana caranya mengatasi sampah. Rumah tangga menjadi pemberi sampah terbanyak sekitar 75\% dari total volume sampah di Indonesia (Sari et al., 2021).

Sampah diklasifikasikan menjadi Sampah Rumah Tangga (SRT), Sampah Sejenis Rumah Tangga (SSRT), dan sampah spesifik. Sampah rumah tangga adalah sampah yang berasal dari kegiatan seharihari dalam rumah tangga, tidak termasuk tinja dan sampah spesifik. Sampah sejenis sampah rumah tangga berasal dari kawasan komersial, kawasan industri, kawasan khusus, fasilitas sosial, fasilitas umum, dan atau fasilitas lainnya (Suryati et al., 2021).

Pengelolaan sampah rumah tangga umumnya diterapkan dengan memilah sampah organik dan sampah non organik, menerapkan pengelolaan Reduce, Reuse, Recycle (3R) baik berbasis perorangan maupun berbasis masyarakat serta adanya pengangkutan sampah menuju tempat pembuangan sementara (TPS) secara rutin sebelum tahap akhir atau tahap pemusnahan. Pengelolaan sampah rumah tangga tersebut dilakukan untuk sampah organik (sisa makanan dan daun kering) dan sampah non organik (sampah kertas, plastik, kaleng, kaca dan bahan rumah tangga lainnya) (Juwono \& Diyanah, 2021).

Sampah masih menjadi persoalan yang belum terkelola dengan baik di berbagai daerah, salah satunya di Desa Bunipah Kecamatan Aluh-Aluh, Kabupaten Banjar, Provinsi Kalimantan Selatan. Desa Bunipah memiliki luas wilayah sebesar $4,48 \mathrm{~km}^{2}$. Wilayah Desa Bunipah Kecamatan Aluh-Aluh terdiri dari 4 RT, dimana sebagian besar wilayah ini merupakan daerah rawa dan sungai, dengan hasil utama adalah padi dan sebagian besar adalah ikan dan udang. Akses daerah di Desa Bunipah masih bisa dilewati mobil ataupun kendaraan bermotor, akan tetapi untuk RT 04 tidak bisa dilewati oleh mobil dan hanya bisa diakses oleh kendaraan karena berada di belakang. Adapun wilayah yang menjadi tempat kegiatan yaitu RT 03 yang berada di bagian ujung desa dan berbatasan dengan Desa Simpang Warga Luar.

Tim pengabdian sudah melakukan kajian permasalahan di RT 03 Desa Bunipah melalui metode survei dan permasalahan utama yang ditemukan yaitu kebiasaan membuang sampah ke sungai dan kebiasaan menimbun sampah. Pembuangan popok sekali pakai (tinja balita), sampah domestik rumah tangga (seperti plastik dan sayur-mayur) dibuang ke sungai dan ke lahan kosong untuk dijadikan halaman rumah. Data sekunder berupa data demografi RT 03 Desa Bunipah (gambaran desa, jumlah penduduk, kartu keluarga) dan data kesehatan Desa Bunipah baik pelayanan maupun non pelayanan yang diperoleh dari bidan Desa Bunipah dan Puskesmas Aluh-Aluh Kecamatan Aluh-Aluh.

Kementerian Lingkungan Hidup dan Kehutanan (KLHK) menyebutkan bahwa jumlah timbulan sampah di Indonesia telah mencapai 175.000 ton/hari atau setara 64 juta ton/tahun dengan pengelolaan yaitu diangkut dan ditimbun di TPA sebanyak $69 \%$, dikubur $10 \%$, dibuat kompos dan didaur ulang $7 \%$, dibakar $5 \%$, dan sisanya tidak terkelola $7 \%$. Mengacu pada data tersebut terlihat saat ini pengelolaan sampah masih terkonsentrasi di Tempat Pemrosesan Akhir (TPA) sampah tanpa melalui proses 3R (reduce, recycle, reuse) di sumber dengan melibatkan partisipasi masyarakat. Kondisi ini menjadi faktor utama beban TPA menjadi berat dan umur penggunaannya semakin pendek (Nugraha et al., 2018).

Berdasarkan komposisinya maka sampah terbagi menjadi jenis sampah organik $60 \%$, plastik $15 \%$, kertas 10\%, dan logam, kaca, kain, kulit 15\%. Sampah organik didominasi oleh sampah makanan (produk 
hewani dan nabati), sayur-sayuran, buah-buahan, limbah ikan, limbah pertanian dan perkebunan, limbah kayu, daun-daunan, ranting, serta kotoran hewan dan manusia. Sampah organik tersebut apabila tidak ditangani dengan baik dapat menjadi sumber penyebab penyakit, menimbulkan bau busuk, mengganggu nilai estetika kota, dan mencerminkan ketidakpedulian pemerintah dan masyarakat akan kebersihan dan kesehatan lingkungan. Selain itu, dapat menjadi sumber pencemar yang menghasilkan limbah cairan lindi mencemari air tanah dan gas metan mencemari udara penyebab pemanasan global (Nugraha et al., 2018).

Kurangnya kesadaran masyarakat dalam hal membuang sampah dan pengelolaan sampah akan berakibat dalam hal partisipasi masyarakat itu sendiri dalam menjaga lingkungan sekitar. Oleh sebab itu, diperlukannya suatu kegiatan untuk menambah pengetahuan serta wawasan masyarakat tentang sampah serta pengelolaannya agar terbentuk kesadaran dan perilaku baik untuk mengelola sampah.

Program pengabdian masyarakat ini bertujuan untuk memberikan pengetahuan untuk mengelola sampah menjadi produk lain yang berdayaguna melalui pelatihan menjadi inovasi yang diperlukan oleh masyarakat Desa Bunipah. Intervensi ini diharapkan mampu menjadi pemicu perubahan perilaku pengelolaan sampah yang kurang benar serta melibatkan partisipasi masyarakat melalui proses $3 R$, sehingga pengelolaan sampah tidak terkonsentrasi hanya di TPA saja yang membuat beban TPA menjadi lebih berat (Yustikarini, 2017). Studi pendahuluan dan karakteristik pengelolaan sampah yang ditunjukkan oleh Masyarakat Bunipah ini menjadi alasan sehingga tim pengabdian memilih Desa Bunipah sebagai sasaran intervensi.

\section{METODE}

Kegiatan pengabdian masyarakat di Desa Bunipah RT 03, Kecamatan Aluh-Aluh Kabupaten Banjar, Kalimantan Selatan merupakan bentuk intervensi dalam kegiatan Pengalaman Belajar Lapangan (PBL) II. Kegiatan ini dilakukan secara daring dengan menggunakan media WhatsApp Group. Intervensi dalam kegiatan ini merupakan pelatihan mengelola sampah. Sasaran dari kegiatan ini adalah masyarakat Desa Bunipah RT 03. Jumlah peserta dalam kegiatan ini sebanyak 13 orang. Narasumber dalam kegiatan ini adalah para dosen dan mahasiswa yang memiliki pemahaman dalam pengelolaan limbah cair dan padat rumah tangga. Metode yang digunakan adalah metode pre-test dan post-test. Sebelum diberikan pelatihan, masyarakat diberikan pre-test untuk mengukur pengetahuan masyarakat terkait sampah dan pengelolaannya. Adapun setelah diberikan pelatihan, masyarakat diberikan soal melalu post-test untuk mengukur pemahaman setelah diberikan intervensi. Media pelatihan yang digunakan dalam kegiatan ini antara poster, booklet, dan video. Poster dan booklet bertujuan untuk memberikan informasi mengenai sampah dan cara pengelolaannya. Poster adalah media gambar yang mengkombinasikan unsur-unsur visual seperti garis, gambar, dan kata-kata untuk dapat menarik perhatian dan mengkomunikasikan pesan secara singkat (Sumartono \& Astuti et al., 2018). Booklet adalah sebuah buku kecil yang memiliki paling sedikit lima halaman tetapi tidak lebih dari empat puluh delapan halaman di luar hitungan sampul (Intika, 2018). Media berupa video berisi cara mengelola sampah menjadi kompos dan kerajinan. Adapun instrumen untuk pengukuran pengetahuan dan sikap responden menggunakan kuesioner dalam bentuk Google Formulir.

Kegiatan ini dilaksanakan pada tanggal 7 sampai dengan 23 November tahun 2020 secara daring melalui WhatsApp Group yang isinya terdiri dari ketua RT, tim pengabdian masyarakat, dan masyarakat Desa Bunipah RT 03. Metode pelaksanaan dalam kegiatan dibagi menjadi 3 tahap yaitu perencanaan dan persiapan, pelaksanaan dan proses, serta monitoring dan evaluasi. Perencanaan merupakan suatu proses untuk menentukan tujuan serta sasaran yang ingin dicapai serta mengambil langkah-langkah 
ABDIMAS: Jurnal Pengabdian Masyarakat Universitas Merdeka Malang

Volume 7, No 1, February 2022: 11-19

strategis guna mencapai tujuan (Batlajery, 2016). Perencanaan dan persiapan berupa proses penyusunan jadwal kegiatan, mengumpulkan kontak sasaran kemudian membuat WhatsApp Group, serta menyusun media intervensi. Pelaksanaan dan proses dalam kegiatan ini diawali dengan pengenalan kegiatan, mengirimkan pre-test ke kelompok sasaran, memberikan pelatihan melalui media poster, booklet, dan video serta terakhir mengirimkan post-test ke kelompok sasaran. Adapun monitoring dan evaluasi dilakukan untuk menilai ketercapaian kegiatan. Indikator keberhasilan kegiatan apabila masyarakat sasaran dapat menjawab minimal 70\% jawaban benar pada kuesioner pengetahuan dan sikap setelah diberikan penyuluhan atau pada saat post-test.

Data pengetahuan dan sikap masyarakat didapatkan dari kuesioner pre-test dan post-test melalui Google Formulir. Analisis data pertama menggunakan uji normalitas. Data dikatakan berdistribusi normal apabila nilai signifikan > 0,05. Apabila data berdistribusi normal maka digunakan uji-T dan apabila data tidak berdistribusi normal maka digunakan uji Wilcoxon. Apabila nilai $p$-value dari uji-T dan uji Wilcoxon $<0,05$, maka ada perbedaan pengetahuan dan sikap responden sebelum dan sesudah diberikan penyuluhan menggunakan melalui WhatsApp Group (Ismail, 2018).

\section{HASIL DAN PEMBAHASAN}

Pengabdian kepada masyarakat pada kegiatan Pengalaman Belajar Lapangan (PBL) II dilaksanakan pada tanggal 7 sampai dengan 23 November tahun 2020. Terdapat beberapa tahapan dalam kegiatan yang dilaksanakan.

\section{Pengenalan kegiatan dan pemberian pre-test}

Kegiatan pengabdian dimulai dengan pengenalan kegiatan kepada masyarakat Desa Bunipah RT 03 melalui Whatsapp Group. Pengenalan kegiatan bertujuan untuk menyampaikan rencana pelaksanaan pelatihan pengelolaan sampah kepada masyarakat sasaran. Tim pengabdian masyarakat memperkenalkan diri serta memberikan informasi mengenai kegiatan yang akan dilaksanakan. Kemudian tim pengabdian masyarakat mengirimkan pre-test ke kelompok sasaran serta memberikan arahan cara mengisi Google Formulir. Soal dalam pre-test dan post-test terbagi menjadi dua yaitu pertanyaan mengenai pengetahuan dan sikap mengenai pengelolaan sampah.

\section{Kegiatan pelatihan pengelolaan sampah}

Adapun pelaksanaan kegiatan merupakan tindak lanjut dari perencanaan yang telah ditentukan untuk mencapai tujuan (Fajri, 2018). Kegiatan pelatihan dilakukan melalui media poster, booklet, dan video. Media poster dan booklet berisi informasi mengenai pentingnya mengelola sampah. Gambar 1 merupakan poster dan booklet yang digunakan dalam kegiatan pelatihan. Masyarakat diberikan kesempatan untuk membaca poster dan booklet secara mandiri kemudian dilakukan proses diskusi antara tim pengabdian beserta masyarakat.

Adapun media pelatihan berupa video berisi cara mengelola sampah menjadi kompos dan kerajinan sehingga memiliki nilai guna dan dapat dimanfaatkan oleh masyarakat. Gambar 2 merupakan video cara membuat kompos dan membuat kerajinan berbahan dasar botol. Video pelatihan dibuat langsung oleh tim peneliti. Pemberian pelatihan pengelolaan sampah melalui video bertujuan untuk meningkatkan minat masyarakat untuk turut mempraktikkan. Cara membuat kompos dan kerajinan dari sampah dibuat menarik. Langkah-langkah pembuatan kompos dan kerajinan dibuat sederhana. Bahan yang digunakan adalah bahan yang mudah didapat sehingga diharapkan dapat mempermudah masyarakat untuk mempraktikkan di lingkungan masing-masing. 

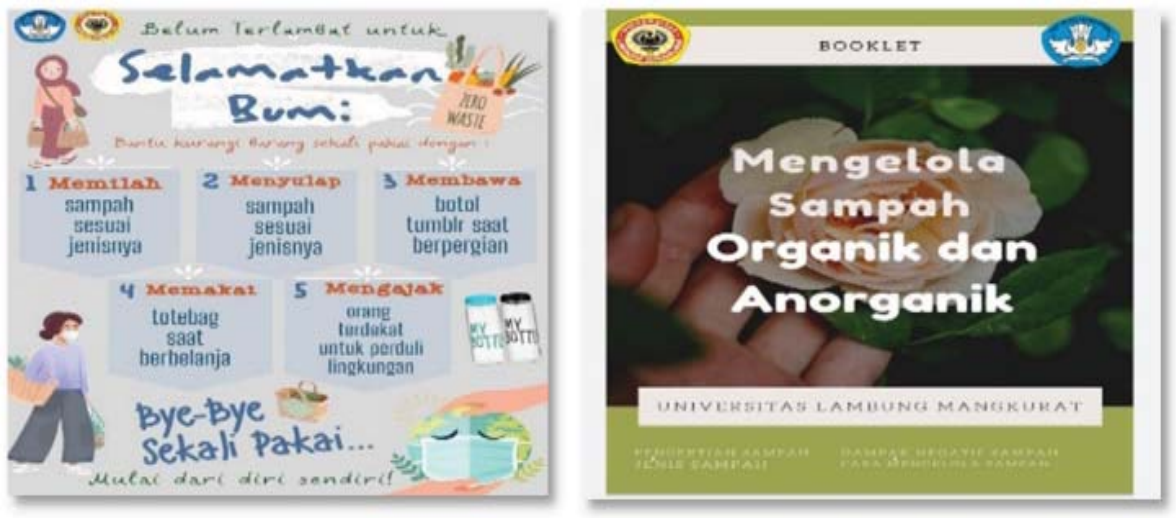

Gambar 1. Media kegiatan berupa poster dan booklet
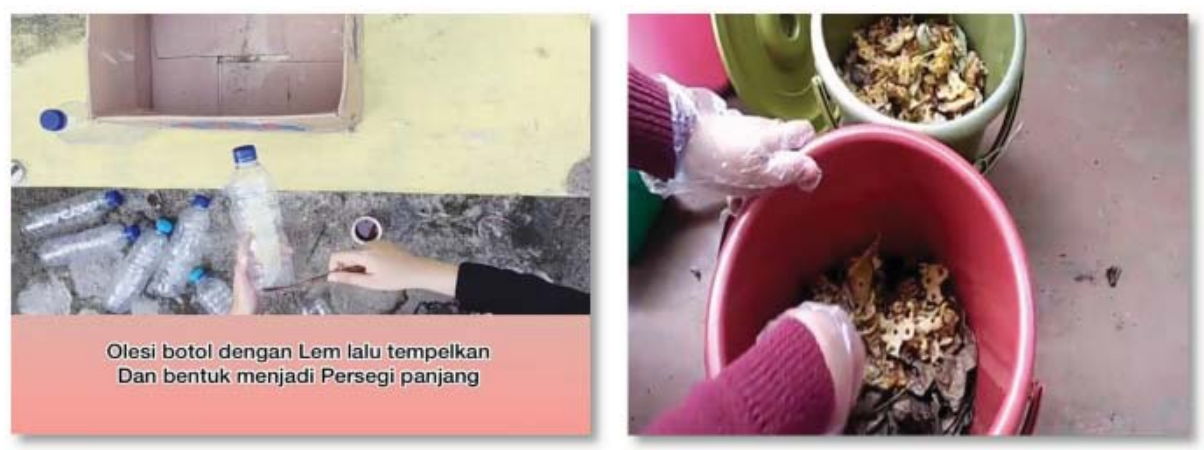

Gambar 2. Video cara membuat kompos

Video pelatihan diberikan kepada masyarakat melalui WhatsApp Group. Gambar 3 menunjukkan kegiatan pemberian video pelatihan serta diskusi dengan masyarakat. Kegiatan diskusi membahas permasalahan sampah dan upaya pengelolaan yang masyarakat Desa Bunipah RT 03 lakukan.
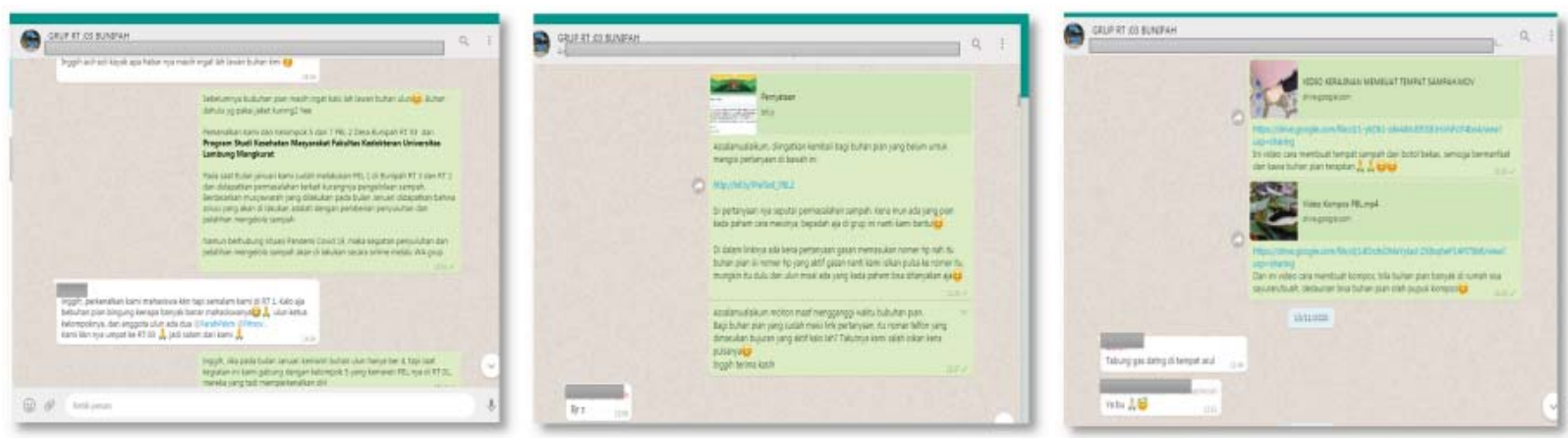

Gambar 3. Pelaksanaan kegiatan

\section{Hasil pre-test dan post-test}

Hasil kegiatan memuat distribusi frekuensi pengetahuan dan sikap masyarakat mengenai pengelolaan sampah. Serta hasil uji statistik untuk melihat perbedaan antara pengetahuan dan sikap sebelum intervensi dan sesudah intervensi. Hasil tersebut dapat dilihat pada Tabel 1. 
ABDIMAS: Jurnal Pengabdian Masyarakat Universitas Merdeka Malang

Volume 7, No 1, February 2022: 11-19

Tabel 1. Distribusi frekuensi pengetahuan dan sikap masyarakat terkait pengelolaan sampah

\begin{tabular}{|c|c|c|}
\hline & Jumlah Orang (n) & Presentase (\%) \\
\hline \multicolumn{3}{|c|}{ Pengetahuan } \\
\hline Baik & 12 & 92,3 \\
\hline Kurang & 1 & 7,7 \\
\hline \multicolumn{3}{|c|}{ Post test } \\
\hline Baik & 12 & 92,3 \\
\hline Kurang & 1 & 7,7 \\
\hline \multicolumn{3}{|l|}{ Sikap } \\
\hline \multicolumn{3}{|l|}{ Pre test } \\
\hline Baik & 12 & 92,3 \\
\hline Kurang & 1 & 7,7 \\
\hline \multicolumn{3}{|c|}{ Post test } \\
\hline Baik & 13 & 100 \\
\hline Kurang & - & - \\
\hline
\end{tabular}

Berdasarkan hasil nilai dari pre-post test masyarakat Desa Bunipah RT 03 didapati bahwa pengetahuan masyarakat terkait pengelolaan sampah setelah dilakukan intervensi meningkat sebesar $69,2 \%$ dan sikap meningkat sebesar $84,6 \%$. Sedangkan, berdasarkan hasil uji statistik dapat dilihat pada Tabel 2.

Tabel 2. Hasil uji statistik

\begin{tabular}{lll}
\hline \multicolumn{1}{c}{ Kategori } & \multicolumn{1}{c}{ Uji statistik } & Hasil \\
\hline Pengetahuan & Uji wilcoxon & 0,011 \\
Sikap & Uji t (Paired sample t test) & 0,941 \\
\hline
\end{tabular}

Pada Tabel 2 terlihat nilai Sig $(0,011)<0,05$ yaitu Ho diterima yang artinya ada perbedaan yang signifikan antara pengetahuan masyarakat Desa Bunipah RT 03 pada saat pengisian kuesioner sebelum dan sesudah pelatihan.

Pengetahuan merupakan hasil tahu dari manusia setelah melakukan penginderaan terhadap suatu objek tertentu sehingga membuat seseorang mampu untuk mengambil suatu keputusan (Haryathi et al., 2019). Pengetahuan responden mengalami peningkatan setelah diberikan pelatihan. Sebagian besar responden sudah memiliki pengetahuan yang baik, mereka sudah bisa membedakan sampah organik dan anorganik, mengetahui dampak dari sampah, serta pengelolaannya. Hasil penelitian ini sejalan dengan penelitian yang dilakukan oleh Haryathi et al. (2019), tentang pengaruh penggunaan jejaring sosial WhatsApp terhadap pengetahuan remaja putri pada kelompok perlakuan dan kelompok kontrol diperoleh nilai $p=0,0001$ sehingga dapat diartikan ada peningkatan pengetahuan remaja putri di STIKES Bina Usada Bali setelah diberikan pendidikan kesehatan melalui jejaring sosial WhatsApp. media WhatsApp merupakan salah satu sarana komunikasi yang memanfaatkan internet dan handphone (HP) yang ditopang oleh aplikasi atau software (Utami et al., 2020).

Hasil penelitian menunjukkan terdapat peningkatan rata-rata nilai pre-test dan post-test terkait sikap masyarakat dalam pengelolaan sampah. Intervensi melalui media WhatsApp juga dilakukan oleh Kristianto (2018), dalam upaya meningkatkan derajat kesehatan gigi dan mulut, hasil penelitian menunjukkan bahwa ada perbedaan terhadap peningkatan kebersihan gigi dan mulut antara kelompok yang diberikan intervensi WhatsApp dan kelompok yang tidak diberikan WhatsApp. Namun, berdasarkan hasil Uji-T yang dilakukan dalam penelitian ini nilai Sig $(0,941)>0,05$ yaitu Ho diterima yang artinya tidak 
ada perbedaan antara sikap masyarakat Desa Bunipah RT 03 pada saat pengisian kuesioner sebelum dan sesudah penyuluhan. Penelitian ini sejalan dengan penelitian oleh Firliana \& Arifin (2020), menunjukkan hasil bahwa penyuluhan secara signifikan dapat meningkatkan nilai rata-rata sikap masyarakat terhadap pengelolaan sampah rumah tangga, akan tetapi tidak ada perbedaan nilai rata-rata sikap setelah dilakukan uji statistik.

Sikap dapat dipengaruhi oleh pengetahuan. Pengetahuan merupakan faktor kekuatan terjadinya perubahan sikap. Sikap responden yang baik didukung dengan pengetahuan mereka yang baik. Akan tetapi, pengetahuan yang baik belum sepenuhnya dapat merubah sikap masyarakat. Hal ini disebabkan karena sikap terbentuk secara bertahap, dalam mengubah sikap seseorang dapat dilakukan dengan kegiatan yang berulang dan terus menerus sehingga informasi secara bertahap akan diserap oleh individu. Sehingga pemberian intervensi yang dilakukan sekali saja masih belum cukup dalam membentuk perubahan sikap positif di masyarakat (Firliana \& Arifin, 2020).

Kegiatan pemberdayaan masyarakat melalui media WhatsApp juga telah dilakukan oleh Hudri \& Nurhayati (2020). Dalam hasil penelitiannya diketahui bahwa pelatihan melalui media WhatsApp dapat menjadi tempat sharing, dan konsultasi antara tutor dengan warga belajarnya. Selain itu media WhatsApp dapat mempermudah tutor dalam menyampaikan materi.

\section{SIMPULAN DAN SARAN}

Masyarakat Desa Bunipah RT 03 dalam kategori pengetahuan terkait pengelolaan sampah setelah dilakukan intervensi meningkat sebesar $69,2 \%$. Pada uji statistik dengan menggunakan uji Wilcoxon didapatkan nilai Sig $(0,011)<0,05$ yaitu Ho diterima yang artinya ada perbedaan yang signifikan antara pengetahuan masyarakat Desa Bunipah RT 03 pada saat pengisian kuesioner sebelum dan sesudah pelatihan. Sedangkan kategori sikap pada masyarakat Desa Bunipah RT 03 juga mengalami peningkatan sebesar $84,6 \%$. Pada uji statistik sikap menggunakan uji-T (Paired sample $T$ test) yang menunjukkan nilai Sig $(0,941)>0,05$ yaitu Ho diterima yang artinya tidak ada perbedaan antara sikap masyarakat Desa Bunipah RT 03 pada saat pengisian kuesioner sebelum dan sesudah pelatihan.

Perlu dilakukan sosialisasi tambahan mengenai pengelolaan sampah organik dan anorganik kepada masyarakat secara langsung yang dilakukan oleh kader kesehatan dan aparat desa, dikarenakan kegiatan ini sebelumnya dilaksanakan oleh tim pengabdian masyarakat secara daring online akibat pandemi COVID-19, sehingga tidak meratanya pemberian informasi kepada seluruh aspek masyarakat Desa Bunipah RT 03. Selain itu, perlu adanya kerjasama dengan mitra-mitra lain diluar dari Desa Bunipah RT 03 agar pengetahuan lebih luas dan mendalam terkait pembuatan pengelolaan sampah serta menghasilkan kerajinan tangan yang bisa mengangkat perekonomian masyarakat.

\section{UCAPAN TERIMA KASIH}

Terima kasih kepada Kepala Desa Bunipah dan ketua RT 03 telah membantu dalam kegiatan ini, serta tim pengabdian masyarakat dalam penyusunan laporan dan pelaksanaan kegiatan ini sehingga kegiatan ini dapat berjalan lancar sesuai dengan yang diharapkan. 
ABDIMAS: Jurnal Pengabdian Masyarakat Universitas Merdeka Malang

Volume 7, No 1, February 2022: 11-19

\section{DAFTAR PUSTAKA}

Batlajery, S. (2016). Penerapan fungsi-fungsi manajemen pada aparatur pemerintahan Kampung Tambat Kabupaten Merauke. Jurnal Ilmu Ekonomi \& Sosial, 7(2), 135-155. https://doi.org/10.35724/jies.v7i2.507

Fajri, R. N. (2018). Perencanaan, pelaksanaan, penulisan laporan pemagangan (Panduan praktis mahasiswa yang akan menyongsong dunia kerja yang disertai dengan contoh laporan magang). Deepublish.

Firliana, E. \& Arifin, Z. (2020). Efektivitas penyuluhan individual dan kelompok dalam meningkatkan pengetahuan, sikap, dan perilaku pengelolaan sampah rumah tangga berkonsep 3R (Studi kasus di Kelurahan Abadijaya Kota Depok tahun 2018). Jurnal Nasional Kesehatan Lingkungan Global, 1(3). http://dx.doi.org/10.7454/jukl.v1i3.4237

Hardiyanti, K. (2021). Evaluasi kebijakan pengelolaan sampah di Kabupaten Demak. Jurnal Administrasi Publik, 11(2). https://doi.org/10.31289/publika.v9i1.4301

Haryathi, N. L. P. Y., Nyandra, M. \& Hardy, I. P. D. K. (2019). Penggunaan jejaring sosial Whatsapp sebagai media promosi terhadap pengetahuan dan perilaku SADARI pada remaja putri di STIKES Bina Usada Bali. In Seminar Ilmiah Nasional Teknologi, Sains, dan Sosial Humaniora (SINTESA), 2(1).

Hudri, I., \& Nurhayati, S. (2020). Pemanfaatan aplikasi Whatsapp pada pelatihan kerajinan kain flanel dalam pemberdayaan masyarakat di Bening Saguling Foundation. Comm-Edu (Community Education Journal), 3(3), 238-244. http://dx.doi.org/10.22460/comm-edu.v3i3.4360

Intika, T. (2018). Pengembangan media booklet Science for Kids sebagai sumber belajar di Sekolah Dasar. JRPD (Jurnal Riset Pendidikan Dasar), 1(1), 10-17. https://doi.org/10.26618/jrpd. v1i1.1234

Ismail, H. F. (2018). Statistika untuk penelitian pendidikan dan ilmu-ilmu sosial. Kencana.

Juwono, K. F. \& Diyanah, K. C. (2021). Analisis pengelolaan sampah rumah tangga ( sampah medis dan non medis ) di Kota Surabaya selama pandemi Covid-19. Jurnal Ekologi Kesehatan, 20(1), 12-20. https://doi.org/10.22435/jek.v20i1.3910

Kristianto, J., Priharti, D. \& Abral, A. (2018). Efektifitas peyuluhan kesehatan gigi dan mulut dengan media video melalui whatsapp dalam meningkatkan derajat kesehatan gigi dan mulut di Panti Asuhan Yos Sudarso Jakarta. Quality: Jurnal Kesehatan, 12(1), 8-13. https://doi.org/10.36082/qjk.v12i1.24

Nugraha, A., Sutjahjo, S. H. \& Amin, A. A. (2018). Analisis persepsi dan partisipasi masyarakat terhadap pengelolaan sampah rumah tangga di Jakarta Selatan. Journal of Natural Resources and Environmental Management, 8(1), 7-14. https://doi.org/10.29244/jpsl.8.1.7-14

Sari, M. P., Musniati, N., Zannah, R., \& Zazhilla, A. (2021). Sosialisasi pemilihan sampah rumah tangga untuk meningkatkan pengetahuan anak-anak dalam pengolahan sampah di Yatim Piatu Muhammadiyah Tanah Abang. Jurnal SOLMA, 10(1), 202-209.

https://doi.org/10.22236/solma.v10i1.4949

Sari, M., Lestari, S. U. \& Awal, R. (2018). Peningkatan ketrampilan mahasiswa dalam pengelolaan sampah organik untuk mewujudkan green campus di Universitas Lancang Kuning. Dinamisia: Jurnal Pengabdian Kepada Masyarakat, 2(2), 193-196.

https://doi.org/10.31849/dinamisia.v2i2.1392 
Training on waste management into a useful product in Bunipah Village, Banjar Regency

Mufatihatul Aziza Nisa, Nur Lina Wati, Aprilia Artati Nur, Fitria Fitria, Karina Nurfatma Apriani, Reki Ranggafu Fajrin

Sumartono, S., \& Astuti, H. (2018). Penggunaan poster sebagai media komunikasi kesehatan. Komunikologi: Jurnal Ilmiah Ilmu Komunikasi, 15(1).

Suryati, K., Agustikawati, N. \& Hamid, A. (2021). Pengaruh sikap terhadap perilaku masyarakat dalam pengelolaan sampah rumah tangga di Desa Pungkit Kecamatan Moyo Utara Kabupaten Sumbawa. Jurnal Kesehatan dan Sains, 4(2), 67-75. https://doi.org/10.51487/jks.v4i2.71

Undang-undang RI (2008). Undang-Undang Republik Indonesia Nomor 18 Tahun 2008 Tentang Pengelolaan Sampah.

Utami, R. B., Sari, U. S. C. \& Sopianingsih, J. (2020). Efektifitas penggunaan media melalui whatsapp dan booklet terhadap sikap ayah asi di wilayah kerja Puskesmas Tuan Tuan Kecamatan Benua Kayong Kabupaten Ketapang. Jurnal Kebidanan Khatulistiwa, 6(2), 83-90. https://doi.org/10.30602/jkk.v6i2.581

Yustikarini, R., Setyono, P., \& Wiryanto, W. (2017). Evaluasi dan kajian penanganan sampah dalam mengurangi beban tempat pemrosesan akhir sampah di TPA Milangasri Kabupaten Magetan. In Proceeding Biology Education Conference: Biology, Science, Enviromental, and Learning, 14(1), 177-185. 